\title{
Effect of Ferula Elaeochytris Root Extract on Smooth Muscle Contraction of Prostate Gland in Rat
}

\author{
Ozge Ozturk Cimentepe ${ }^{1}$, Cemil Gocmen ${ }^{1}$, Nadire Eser $^{2}$, \\ Hacer Sinem Buyuknacar ${ }^{3}$, Mehmet Cimentepe $^{4}$
}

10.18805/ag.D-354

\begin{abstract}
Background: Smooth muscle contraction and enlargement of the prostate are important targets for the treatment of lower urinary tract symptoms in patients with benign prostatic hyperplasia. The effect of Ferula elaeochytris (FE) root extract on tissues that play a role on fertility such as the prostate has not been demonstrated yet. The aim of this study is to investigate the effects of FE extract on isolated rat prostate tissue induced by electrical field stimulation (EFS) in vitro.

Methods: In this experimental study, 48 male rats were randomly divided into 6 groups $(n=8)$. Groups were consisting FE $(20 \mu l)$, FE + Adenosine triphosphate (ATP; $50 \mu \mathrm{M}), \mathrm{FE}+\operatorname{prazosin}(0.3 \mu \mathrm{M}), \mathrm{FE}+$ Calcium $\left(\mathrm{Ca}^{2+} ; 3 \mathrm{mM}\right.$ and $\left.6 \mathrm{mM}\right), \mathrm{FE}+\mathrm{suramin}(100 \mu \mathrm{M}), \mathrm{FE}$ + phenylephrine and FE + carbachol.

Result: In our study, FE extract inhibited the neurogenic contractions induced by EFS on isolated rat anterior prostate tissue. The presence of suramin and prazosin were not significantly increase the inhibition caused by the FE extract, while $\mathrm{Ca}^{2+}$ and ATP significantly increased the inhibition by the FE extract. $(p<0.05)$. In addition, FE extract significantly inhibited phenylephrine and carbachol contractions $(p<0.05)$.
\end{abstract}

Key words: Electrical field stimulation (EFS), Ferula elaeochytris, Prostate, Smooth muscle.

\section{INTRODUCTION}

Prostate smooth muscle contraction and enlargement of the prostate contribute to the development of lower urinary tract symptoms in patients with benign prostatic hyperplasia (BPH) by disrupting bladder emptying due to proximal urethral obstruction (Hennenberg et al. 2014). Induction of prostate smooth muscle relaxation is an important goal for the medical treatment of voiding symptoms. $\alpha 1$-adrenoceptor antagonists ( $\alpha 1$-blockers) are used to improve symptoms by inducing prostate smooth muscle contraction (Oelke et al. 2013). However, prostatic smooth muscle contraction is mediated by numerous other receptor systems, such as acetylcholine acting on muscarinic receptors or ATP acting on purinoceptors. For this reason, it has been postulated that blocking these receptors, particularly muscarinic receptors, is an appropriate additional target for a better pharmacological treatment for BPH. ATP causes smooth muscle contractions in rat and guinea pig prostates by activation of purinergic receptors. Purinergic contractions mediate contraction via P2X1 purinoceptors located on prostatic smooth muscle (Burnstock et al. 2011, Ralevic 2015).

The genus Ferula L. (Apiaceae) includes approximately 180-185 species distributed from Asia, North Africa to North America. It is represented by 23 taxon in flora of Turkey, 13 of which are endemic and the mainly distributed Mediterranean, Southeast and Central Asia Innor Anatolia. Most of the species are known as "flint, calendula, and pulp" and are used in Anatolian traditional medicine as an aphrodisiac, tonic, antimicrobial, expectorant in hemorrhoids
${ }^{1}$ Department of Pharmacology, Faculty of Medicine, Cukurova University, Adana, Turkey.

2Department of Pharmacology, Faculty of Medicine, Kahramanmaras Sutcu İmam University, Kahramanmaras, Turkey.

${ }^{3}$ Department of Pharmacology, Faculty of Pharmacy, Cukurova University, Adana, Turkey.

${ }^{4}$ Department of Medical Microbiology, Faculty of Medicine, Cukurova University, Adana, Turkey.

Corresponding Author: Ozge Ozturk Cimentepe, Department of Pharmacology, Faculty of Medicine, Cukurova University, Adana, Turkey. Email: ozge-ozturk01@hotmail.com

How to cite this article: Cimentepe, O.O., Gocmen, C., Eser, N., Buyuknacar, H.S., Cimentepe, M. (2021). Effect of Ferula Elaeochytris Root Extract on Smooth Muscle Contraction of Prostate Gland in Rat. Agricultural Science Digest. DOI: 10.18805/ ag.D-354.

Submitted: 02-04-2021 Accepted: 10-07-2021 Online: 03-08-2021

and urinary diseases (Altundag et al. 2011, Güzel et al. 2015, Sargin et al. 2015). The components and fatty acids in FE root extract were determined by GC/MS (Eser et al. 2019 and 2020). It has been shown that FE has a high capacity for total phenolic content and reduces glucose levels (Eser et al. 2020). Also, the corrective effects of FE on diabetes (Eser et al. 2020) and age (Eser et al. 2020) related erectile dysfunction have been demonstrated. Syriaca root extract has been used as a smooth muscle relaxant in the human corpus cavernosum. In addition, some substances found in this species have been shown to have potent antiproliferative 
and cytotoxic effects (Ozturk et al. 2012). There is limited data on the effects of FE root extract on prostate smooth. The aim of this study is to investigate the effects of FE extract on isolated rat prostate smooth muscle tissue induced by EFS in vitro.

\section{MATERIALS AND METHODS}

\section{Animals}

A group of healty male Wistar albino rats $(200-250 \mathrm{~g})$ with an age group of approximately 3 months obtained from Medicine Research Laboratories of Cukurova University, Turkey were used for present study. All experimental procedures were approved by the Cukurova University Animal Experiments Local Ethics Committee (Approval No: 02.10.2013 3/10). A total of 48 male rats were housed in a room with controlled temperature $\left(24 \pm 2^{\circ} \mathrm{C}\right)$, humidity $(45$ $55 \%$ ) and a 12 hour light to 12 hour dark photoperiod. They received standard food and tap water ad libitum.

\section{Preparation of FE extract}

FE was collected by the author in Engizek Plateau Kahramanmaraş $\left(37^{\circ} 33^{\prime} 39^{\prime \prime} \mathrm{N}, 41^{\circ} 45^{\prime \prime} 53^{\prime \prime} \mathrm{E}\right)$ in 2013. FE was defined and verified by Pr. Dr. Ihan Uremis (taxonomist). FE extraction was carried out at Cukurova University. All plant material was dried under the shade and mechanically pulverized. Crude root extract was prepared using the Soxhlet extraction method (Bimakr et al. 2011). Twenty grams of the powdered flint root was taken and extracted in Soxhlet apparatus by keeping in $320 \mathrm{ml}$ diethyl ether solvent at $60^{\circ} \mathrm{C}$ for 4 hours. At the end of the extraction, the balloon containing the solvent was removed and connected to the evaporator. The solvent was removed. The balloon was then kept in the oven set at $60^{\circ} \mathrm{C}$ for 1 hour, cooled to room temperature in the desiccator and weighed. The dried extract was kept at $4^{\circ} \mathrm{C}$.

\section{In vitro analysis of isolated prostate tissue}

The rats were killed by cervical dislocation under isoflurane anesthesia, the abdominal part was opened and two lobes were removed from the prostate. The operation was carried out as previously described as in our previous study (Eser et al. 2020). Then, these tissues were isolated in a petri dish containing Krebs solution $(119 \mathrm{mM} \mathrm{NaCl}, 4.6 \mathrm{mM} \mathrm{KCl}$,

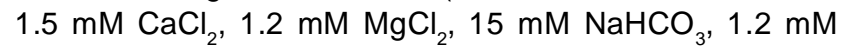
$\mathrm{NaHPO}_{4}$ and $11 \mathrm{mM}$ glucose) and made into 4 separate strips. Prostate strips were suspended between electrodes containing platinum under 1 gram of tension in $5 \mathrm{ml}$ isolated organ baths ventilated with $5 \% \mathrm{CO}_{2}$ and $95 \% \mathrm{O}_{2}$ heated at $37^{\circ} \mathrm{C}$ containing Krebs solution. Tissues were left to incubate for 1 hour. The responses were recorded with isometric transducers (May FDT 10 A; Commat Ltd., Ankara, Turkey) on a two-channel recorder (Biopac MP36 Systems, Santa Barbara, CA, USA).

After incubation, progressively isometric contractions of the prostate tissues were induced using EFS $(2,4,8 \mathrm{~Hz}$, $50 \mathrm{~V}, 0.5 \mathrm{~ms}$ duration, $10 \mathrm{~s}$ trainler) sequences sent from a Grass S88 stimulator via two parallel platinum electrodes embedded in Perspex. Tissues were washed with Krebs solution. Aftewards, FE $(20 \mu \mathrm{l}$ as a result of our pilot study with different doses 2.5, 5, 10 and $20 \mu$ l) extract was added to the bath and kept for 10 minutes. For each study, $\mathrm{Ca}^{2+}(3$ $\mathrm{mM}$ and $6 \mathrm{mM}$ ), ATP (purinergic receptor agonist; $50 \mu \mathrm{M}$ ), suramin (purinergic receptor antagonist; $100 \mu \mathrm{M}$ ) and prazosin (adrenergic receptor antagonist; $0.3 \mu \mathrm{M}$ ) was added to the bath and for kept for 10 minutes in the presence of FE extract. Neurogenic contractions were form with EFS. To examine the changes in the contractile length of tissues, phenylephrine ( $\alpha 1$ adrenergic receptor agonist; $50 \mu \mathrm{M}$ ) and carboccol (cholinergic receptor agonist; $50 \mu \mathrm{M}$ ) were administered and the contraction length was observed. FE extract was given to examine the changes in the length of the contraction. After that, the tissue was washed with fresh Krebs solution and allowed to rest for $30 \mathrm{~min}$. At the end of the study, the experiments were completed by contracting the tissues with Krebs solution containing $100 \mathrm{mM} \mathrm{KCl}$.

\section{Statistical analysis}

The quantified by calculation the maximal amplitude $(\mathrm{mg})$, Amplitudes of neurogenic contractions induced by EFS were expressed as a percentage of control EFS contractions (without drugs) at the each experiment. All data are expressed as mean \pm S.E.M. All of the data were evaluated with the Bonferroni corrected t test that was used in analysis of variance (ANOVA). $p$ values of less than 0.05 were considered significant. Statistical analysis was performed with GraphPad Prism software (San Diego, CA, USA).

\section{RESULTS AND DISCUSSION \\ Effect of FE extract using ethyl alcohol as solvent on neurogenic contractions induced by EFS}

In control experiments without any antagonist, EFS (2, 4, 8 $\mathrm{Hz}, 50 \mathrm{~V}, 0.5 \mathrm{~ms}$ duration, $15-30$ seconds) produced a bimodal contraction in the prostate tissue consisting of a large amplitude transient response followed by a lower amplitude more sustained response. FE root extract $(20 \mu \mathrm{l})$ significantly reduced EFS induced neurogenic contractions in isolated rat anterior prostate tissue (Fig 1). Ethyl alcohol $(20 \mu \mathrm{l})$ was given in a $5 \mathrm{ml}$ bath medium on neurogenic contractions induced by EFS in the prostate tissue and no change was observed on neurogenic contractions (Fig 2).

\section{Effect of FE extract on neurogenic contractions induced by EFS in the presence of ATP, prazosin, suramin and $\mathrm{Ca}^{2+}$}

On isolated rat prostate tissue, FE extract significantly reduced neurogenic contractions induced by EFS (2, 4, 8 $\mathrm{Hz}, 50 \mathrm{~V}, 0.5 \mathrm{~ms}, 15-30$ seconds) (Fig 3). In the presence FE extract, the prurinergic responses to EFS $(4 \mathrm{~Hz}, 50 \mathrm{~V}$, $0.15 \mathrm{~ms}$ ) were significantly corrected by ATP in the prostate tissue (Fig 3). Further, $\alpha 1$-adrenergic receptor blocker, prazosin $(0.3 \mu \mathrm{M})$ and purinergic receptor blocker suramin $(100 \mu \mathrm{M})$ failed to modify the contractile response induced by EFS in the presence of FE extract (Fig 4 and 5). In additon, it was observed that $3 \mathrm{mM} \mathrm{Ca}^{2+} 2 \mathrm{~Hz}$ and $8 \mathrm{~Hz}$ frequencies except $4 \mathrm{~Hz}$ and all frequencies of $6 \mathrm{mM} \mathrm{Ca}^{2+}$ significantly corrected the inhibition in the presence of FE extract (Fig 6). 
Effect of FE extract on the contractile response induced by phenylephrine and carbachol

In the presence phenylephrine, the adrenergic responses to $\operatorname{EFS}(2,4,8 \mathrm{~Hz}, 50 \mathrm{~V}, 0.5 \mathrm{~ms}$ duration, $15-30$ seconds) were significantly inhibited by FE extract at the prostatate tissue. In additon, the cholinergic responses to EFS (2, 4, 8 $\mathrm{Hz}, 50 \mathrm{~V}, 0.5 \mathrm{~ms}$ duration, $15-30$ seconds) were significantly inhibited by FE extract in the presence carbachol (Fig 7).

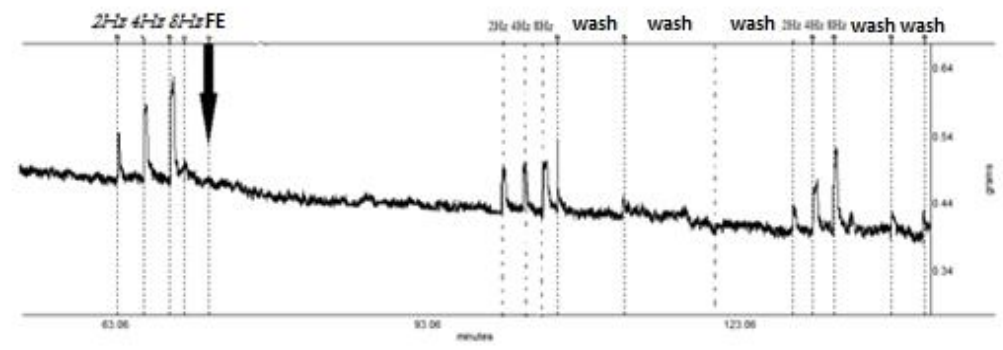

Fig 1: Effects of FE extract on neurogenic contractions induced by EFS (2, 4, $8 \mathrm{~Hz}, 50 \mathrm{~V}, 0.5 \mathrm{~ms}, 15-30$ seconds) on isolated rat anterior prostate tissue.

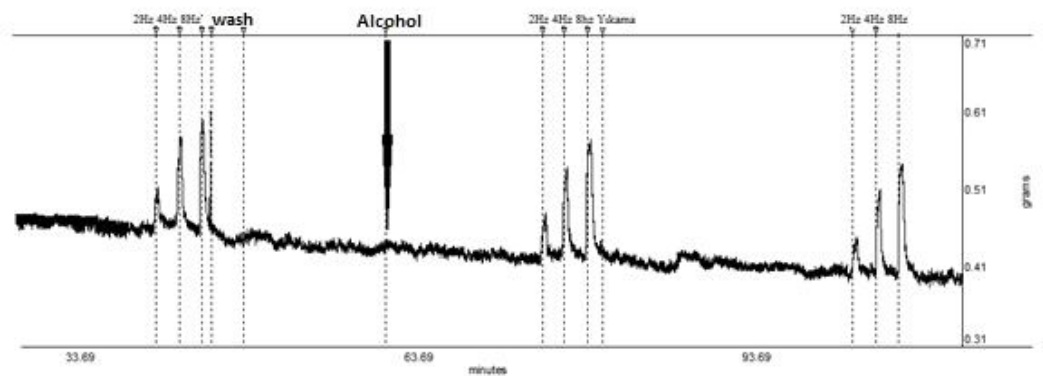

Fig 2: Effects of Ethyl alcohol on neurogenic contractions induced by EFS (2, 4, $8 \mathrm{~Hz}, 50 \mathrm{~V}, 0.5 \mathrm{~ms}, 15-30$ seconds) on isolated rat anterior prostate tissue.

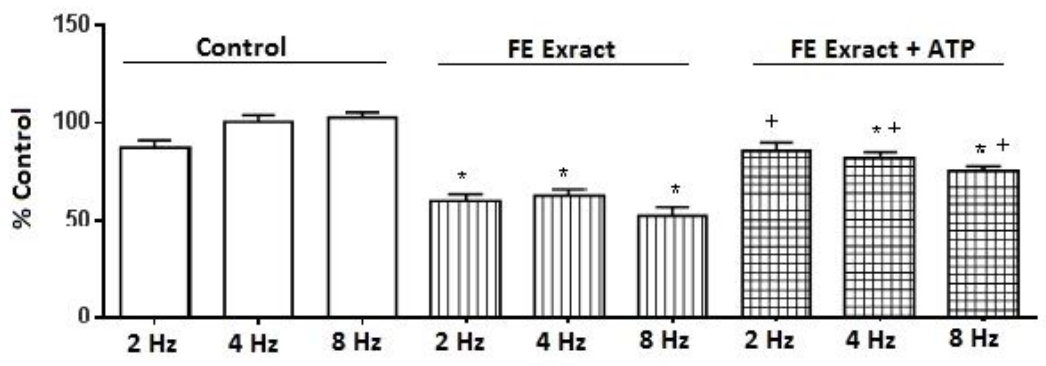

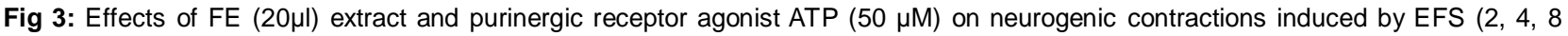
$\mathrm{Hz}, 50 \mathrm{~V}, 0.5 \mathrm{~ms}, 15-30$ seconds) on isolated rat anterior prostate tissue. ${ }^{*},+p<0.05$.

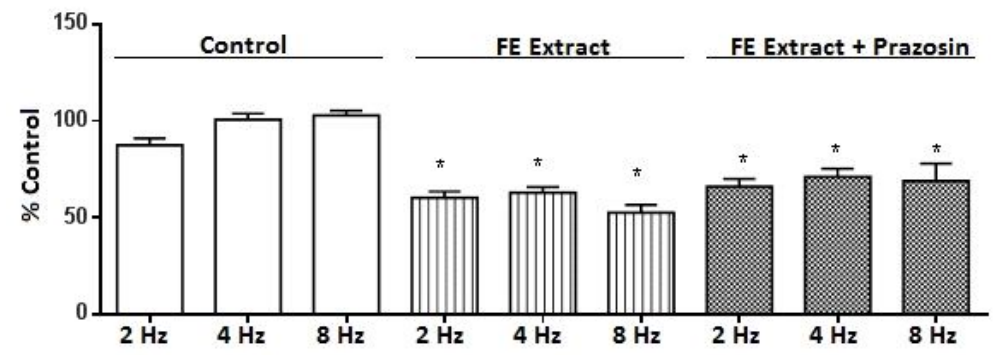

Fig 4: Effects of FE extract $(20 \mu \mathrm{l})$ and $\alpha$-adrenergic receptor blocker prazosin $(0.3 \mathrm{Mm})$ on neurogenic contractions induced by EFS $\left(2,4,8 \mathrm{~Hz}, 50 \mathrm{~V}, 0.5 \mathrm{~ms}, 15-30\right.$ seconds) on isolated rat anterior prostate tissue. ${ }^{*} \mathrm{p}<0.05$. 
EFS application stimulates all neuron networks in the prostate wall and therefore stimulate smooth contraction both directly and indirectly. The nature of the contraction depends on the contribution of the types of neurotransmitters released during the stimulation periods (Yu et al. 2018). In our study, EFS induced smooth muscle contraction FE extract decreased rat prostate smooth muscle contractions in a dose-dependent and significant way. These inhibitions were reserved as a result of washing the medium with fresh Krebs solution and the contractions were restored. Since this reversible and dose-dependent inhibition, it has shown that the FE extract had a pharmacological effect on smooth muscle function.

Considering that $\alpha 1$ blockers represent the first line option for the medical treatment of voiding symptoms in $\mathrm{BPH}$, a1-adrenergic and EFS induced contractions can be considered the gold standard of prostate smooth muscle contraction. $\alpha 1$ blockers can reduce prostate tone and BOO by inhibiting the effect of endogenously released noradrenaline on prostate smooth muscle cells (Ventura et al. 2011). Previous studies have reported purinergic smooth muscle contractions in rat prostates with contractile forces approaching the range of neurogenic and $\alpha 1$-adrenergic contractions (Oelke et al. 2013, Hennenberg et al. 2013). In EFS induced muscle contractions, which are presumed to be mediated by the release of endogenous neurotransmitters and greater activation of postsynaptic a1-adrenoceptors on smooth muscle cells, the FE extract was inhibited contractions and the $\alpha 1$ adrenergic receptor blocker prazosin and purinergic receptor blocker suramin in the presence of FE extract was no effect on contractions. These results was not correlate the inhibitory effect of the inhibition of FE extract with adrenergic and purinergic pathways on the EFS induced contractile responses. However, inhibition of adrenergic

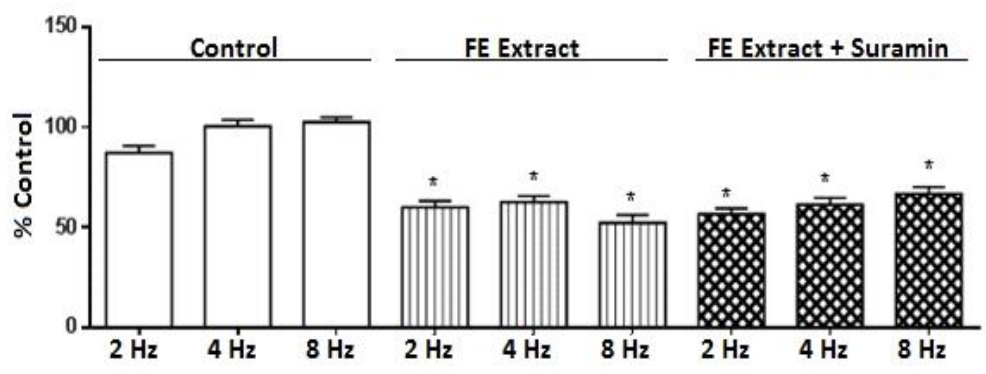

Fig 5: Effects of FE extract $(20 \mu \mathrm{l})$ and purinergic receptor blocker suramin $(100 \mu \mathrm{M})$ on neurogenic contractions induced by EFS (2, $4,8 \mathrm{~Hz}, 50 \mathrm{~V}, 0.5 \mathrm{~ms}, 15-30$ seconds) on isolated rat anterior prostate tissue. ${ }^{*} \mathrm{p}<0.05$.

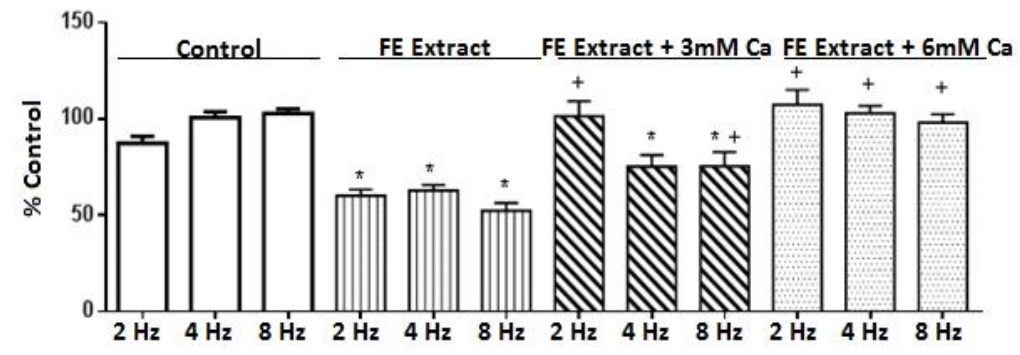

Fig 6: Effects of FE extract $(20 \mu \mathrm{l})$ and $\mathrm{Ca}^{2+}(3 \mathrm{mM}$ and $6 \mathrm{mM})$ on neurogenic contractions induced by EFS $(2,4,8 \mathrm{~Hz}, 50 \mathrm{~V}, 0.5$ ms, $15-30$ seconds) on isolated rat anterior prostate tissue. ${ }^{*},+p<0.05$.
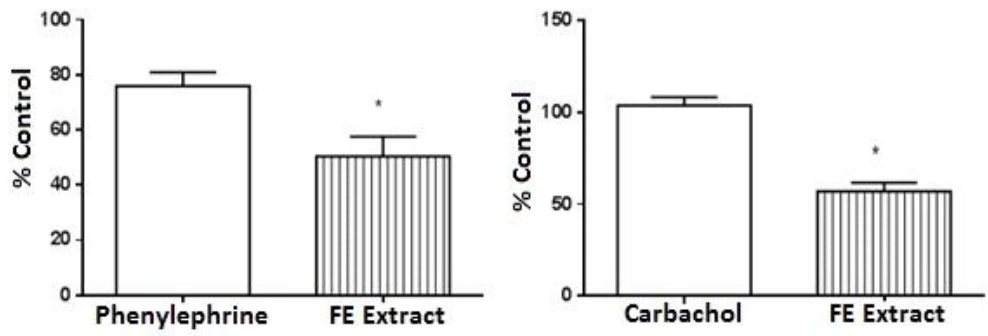

Fig 7: Effect of FE extract (20il) on adrenergic contractions induced by the á adrenergic receptor agonist phenylephrine and cholinergic contractions induced by the cholinergic receptor agonist carbachol on isolated rat anterior prostate tissue. 
contraction by phenylephrine and cholinergic contraction by carbochol were occurred in the presence of FE extract.

It is widely accepted that the increase in free intracellular $\mathrm{Ca}^{2+}$ level is a prerequisite for activating smooth muscle contraction proteins (Webb et al. 2003). $\mathrm{Ca}^{+2}$ sensitivity is important for the ability of smooth muscle cells to maintain their contractile response in the presence of submaximal intracellular $\mathrm{Ca}^{+2}$ levels (Kong et al. 2006). $\mathrm{Ca}^{+2}$ channels play an important role in the control of contractile tone in many smooth muscle cells, including the prostate. Activation of $\mathrm{Ca}^{+2}$ channels causes smooth muscle relaxation through hyperpolarization of the membrane potential (Hughes et al. 2011). The most important finding of our study was that inhibition due to FE extract in the prostate was showed a dosedependent and significant improvement with $\mathrm{Ca}^{+2}$ added to the environment from outside. Inhibition of the EFS response by the FE extract was indicated that activation of $\mathrm{Ca}^{+2}$ channels were contribute greatly to EFS induced contraction. This result showed that the inhibition of FE extract induced inhibition on neurogenic contractions induced by EFS in the rat prostate may be associated with $\mathrm{Ca}^{+2}$ channels.

In addition, inhibition in prostate tissue ATP is an important neurotransmitter that plays a versatile role in the regulation of smooth muscle contraction in the vasculature and various internal organs (Ford et al. 2011). ATP has been reported to cause both smooth muscle contraction and relaxation. It has been assumed that ATP induced contractions have a high importance for the composition of prostate smooth muscle tone (Wang et al. 2020). Various studies with non-human prostates have suggested that ATP can be secreted as a co-transmitter in adrenergic neurotransmission and contribute to the subsequent $\alpha 1$ adrenergic contraction of prostate smooth muscle (Hennenberg et al. 2018, Spek et al. 2021). In addition to ATP induced contractions, inhibition of EFS induced contractions by ATP has also been reported for rat prostate tissues. In our study, it was observed that in the presence of FE extract inhibition of EFS induced smooth muscle contractions and in the presence of FE extract, the purinergic receptor agonist ATP was significantly reversed contractions.

\section{CONCLUSION}

Our most important finding is that the inhibitory effects due to $F E$ on the contractile responses induced by EFS were restored by external addition of $\mathrm{Ca}^{+2}$ into the organ baths these results indicate that the inhibitory effect of FE on neurogenic contractions due to EFS related with $\mathrm{Ca}^{+2}$ channels. In addition, we observed that the inhibitory effects of FE on neurogenic contractions are not related with adrenergic and purinergic pathways. According to our findings we can suggest that FE extract can be tried in the treatment of benign prostatic hyperplasia. So, it is possible this extract increase the cAMP or cGMP in the smooth muscle or this extract may has a possible effect on the PDE 4 or PDE 5 enzyms to induce a relaxation on the prostate tone. However we need some future studies to explain perfect direction of the inhibitory effect of this extract on the tone. FE root can cause infertility in men, as it reduces spontaneous contractions of prostate tissue, which plays a role in fertility, as well as these effects.

\section{REFERENCES}

Altundag, E., Ozturk, M. (2011). Ethnomedicinal studies on the plant resources of East Anatolia, Turkey. Proc-Soc. Behav. Sci. 19: 756-777.

Bimakr, M., Rahman, R.A., Taip, F.S., Ganjloo, A., Salleh, L.M., Selamat, J., et al. (2011). Comparison of different extraction methods for the extraction of major bioactive $\mathrm{fl}$ avonoid compounds from spearmint (Mentha spicata L.) leaves. Food Bioprod. Process. 89: 67-72.

Burnstock, G., Kennedy, C. (2011). P2X receptors in health and disease. Adv Pharmacol. 61: 333-372.

Eser, N., Yoldas, A. (2019). Identification of heat-resistant chemical components of Ferula elaeochytris root extracts by gas chromatography-mass spectrometry. Tropical Journal of Pharmaceutical Research. 18(1): 55-60.

Eser, N., Yoldas, A., Koçer, F. (2020). GC/FID ile ekstrakte edilen Ferula elaeochytris kök ekstresinden ya asidlerinin analizi. Sakarya Medical Journal. 10(2): 264-269.

Eser, N., Kartlasmis, K., Uçar, Y., Kökbas, U. (2020). Total Fenolic Contents of Ferula elaeochytris Root Extract and Its Effect on Glucose Levels. Mersin Üniversitesi Tip Fakültesi Lokman Hekim Tip Tarihi ve Folklorik Tip Dergisi. 10(2): 154-161.

Eser, N., Buyuknacar, H.S., Cimentepe, O.O., Gocmen, C., Ucar, Y., Erdogan, S., et al. (2020). The effect of Ferula elaeochytris root extract on erectile dysfunction in streptozotocininduced diabetic rat. International Journal of Impotence Research. 32(2): 186-194.

Eser, N., Yoldas, A., Yigin, A., Yumusak, N., Bozkurt, A.S., Kokbas, U., et al. (2020). The protective effect of Ferula elaeochytris on age-related erectile dysfunction. Journal of Ethnopharmacology. 258: 112921.

Ford, A.P., Cockayne, D.A. (2011). ATP and P2X purinoceptors in urinary tract disorders. Handb Exp. Pharmacol. 485-526.

Güzel, Y., Güzelşemme, M., Miski, M. (2015). Ethnobotany of medicinal plants used in Antakya: a multicultural district in Hatay Province of Turkey. J. Ethnopharmacol. 174: 118-152.

Hennenberg, M., Stief, C.G., Gratzke, C. (2014). Prostatic a1adrenoceptors: new concepts of function, regulation and intracellular signaling. Neurourol Urodyn. 33(7): 1074-85.

Hennenberg, M., Kuppermann, P., Yu, Q., Herlemann, A., Tamalunas, A., Wang, Y., et al. (2018). Inhibition of prostate smooth muscle contraction by inhib- itors of polo-like kinases. Front Physiol. 9: 734.

Hennenberg, M., Miljak, M., Herrmann, D., Strittmatter, F., Walther, S, Rutz, B, et al. (2013). The receptor antagonist picotamide inhibits ad- renergic and thromboxane-induced contraction of hyperplastic hu- manprostatesmoothmuscle. American Journalof Physiology Renal Physiology. 305: 383-390.

Hughes, J.D, Coles, M.A, Joyce, A. (2011). Calcium channel blocker associated lower urinary tract symptoms in males: an Australian retrospective observational study. Qual Prim Care. 19(4): 223-31. 
Kong, D..H., Zhou, H., Song, J., Ke, D.P., Hu, J.L., Li, ZW., et al. (2006). Capacitative $\mathrm{Ca}+{ }^{2}$ entry is involved in ACh-induced distal colon smooth musclecontraction in rats. Sheng LiXueBao. 58(2): 149-56.

Oelke, M., Bachmann, A., Descazeaud, A., Emberton, M., Gravas, S., Michel, M.C et al. (2013). EAU guidelines on the treatment and follow-up of non-neurogenic male lower urinary tract symptoms including benign prostatic obstruction. Eur Urol. 64: 118-140.

Ozturk, B., Gur, S., Coskun, M., Kosan, M., Erdurak, C.S., Hafez, G., Gonulala, U., Cetinkaya, M.A. (2012). A new relaxant on human corpus cavernosum: Ferulago syriaca root extract, African Journal of Pharmacy and Pharmacology. 6(37): 2652-2656.

Ralevic, V. (2015). P2X receptors in the cardiovascular system and their potential as therapeutic targets in disease. Curr. Med. Chem. 22: 851-865.

Sargin, S.A., Selvi, S., Büyükcengiz, M. (2015). Ethnomedicinal plants of aydıncık district of mersin, Turkey. J. Ethnopharmacol. 174: 200-216.
Spek, A., Li, B., Rutz B., Ciotkowska, A., Huang, R., Liu, Y., et al. (2021). Purinergic smooth muscle contractions in the human prostate: estimation of relevance and characterization of different agonists. Naunyn Schmiedebergs Arch Pharmacol. 394(6): 1113-1131.

Ventura, S., Oliver, V., White, C.W., Xie, J.H., Haynes, J.M., Exintaris, B. (2011). Novel drug targets for the pharmacotherapy of benign prostatic hyperplasia (BPH). Br. J. Pharmacol. 163: 891-907.

Wang, X., Li, B., Ciotkowska, A., Rutz, B., Erlander, M.G, Ridinger, M., et al. (2020). Onvansertib, a polo-like kinase 1 inhibitor, inhibits prostate stromal cell growth and prostate smooth muscle contraction, which is additive to inhibition by alpha1blockers. Eur. J. Pharmacol. 873: 172985.

Webb, R.C. (2003). Smooth muscle contraction and relaxation. Advances in Physiology Education. 27: 201-206.

Yu, Q., Gratzke, C., Wang, Y., Herlemann, A., Sterr, C.M., Rutz, B., et al. (2018). Inhibition of human prostate smooth muscle contraction by the LIM kinase inhibitors, SR7826 and LIMKi3. Br J. Pharmacol. 175: 2077-2096. 